\title{
Political Freedom as an Open Question
}

\author{
Karol Chrobak \\ Warsaw University of Life Sciences - SGGW, Warsaw, Poland \\ karol_chrobak@sggw.pl \\ Received 9 October 2018; accepted 11 January 2019; published 30 June 2019.
}

\begin{abstract}
This essay diagnoses the condition of contemporary liberal democracies. It assumes that the current crisis of democracy is not the result of an external ideological threat, but it is the result of the lack of a coherent vision of democracy itself. The author recognises that the key symptom of the contemporary crisis is the decreasing involvement of citizens in public life and their growing reluctance to participate in public debate. He claims that the reason for this is the increasing social polarisation. The article considers two forms of polarisation: vertical (on the line: politicians-voters) and horizontal (on the line of ideological social divisions). The first form is illustrated by Colin Crouch's considerations, while the second one by Fareed Zakaria's thoughts. What finds its manifestation in both cases is the phenomenon of citizens' resignation from participation in the public debate; in the first case it is because of the lack of faith in the effectiveness of this type of opiniongiving mechanism, while in the second case it is because of the lack of recognition of other political and ideological options in society. These reflections are concluded in the postulate that the basic task facing democracy today is to maintain the public sphere as open as possible, i.e. not excluding any ideological position in advance. This kind of conclusion is illustrated with the concepts of Chantal Mouffe (political perspective) and Helmuth Plessner (philosophical-anthropological perspective).
\end{abstract}

Keywords: democracy; political freedom; social polarisation; post-democracy; illiberal democracy; liberalism.

1.

When discussing the condition of contemporary democracies, attention should be devoted not to threats arising from non-democratic regimes, but to hazards that develop in the bosom of democracy itself. Today, there is no 'significant other' - once embodied by the 
block of communist states - which, in the face of the common threat, would consolidate all actions in favour of democracy. Rather, the problem is that this lack has not been compensated by any 'significant self', i.e. by ideas or beliefs which could motivate democracies towards a stable and peaceful development.

Fareed Zakaria was probably the first researcher who recognised that the biggest problem of democracy is not some kind of its external alternative, but, rather, the fact that the proposal of the democratic order lacks coherence. As he states in the essay titled "The Rise of Illiberal Democracy":

There are no longer respectable alternatives to democracy; it is part of fashionable attire of modernity. Thus the problem of governance in the $21^{\text {st }}$ century will likely be problems within democracy. This makes them more difficult to handle, wrapped as they are in the mantle of legitimacy. (Zakaria, 1997, p. 42)

When locating the source of the crisis within democracy itself, Zakaria points to the whole political system, including its axiological, representative, and institutional structure. I would suggest, however, that the above passage should be read in a more subtle manner. This way, I would like to point to its importance with regard to the subject I intend to deal with here, namely the issue of political freedom. This alternative way of understanding the quoted fragment is rooted in the words of Mikhail Sebastian, written in 1934. In the book titled For Two Thousand Years..., Sebastian writes a passage which aptly corresponds to the above-mentioned Zakaria's statement. He says that:

$[\ldots]$ history is made from within rather than without, from the center rather than periphery. Crudely, we only pick up on the immediate, visible changes that impinge upon our lives. As a result, we imagine that a revolution is first and foremost political and economic upheaval. (Sebastian, 2016, p. 62)

In a manner of excuse, Sebastian accuses the interpreters of history of myopia, which is based on perceiving only large political and economic processes, and on attributing to them a decisive role in historical breakthroughs. These interpretations remain blind to what is the real driving force behind these changes and what, in its psychological subtlety and its 'long duration', escapes the scientific observation. In the case of the contemporary crisis of democracy, this subtle factor seems to be political freedom, understood not in terms of legal guarantees of freedom of speech, the universal right to vote or to peaceful assembly, but in terms of the will to participate in the common governance process, which is hidden in the conscience of every citizen and is based on a delicate responsibility for the common public interest.

2.

When analysing the concept of freedom from a historical perspective, one must first refer to the category of domination. Thus understood, freedom can be considered as dependent on a certain authority (individual or collective), which actually creates the sphere of individual freedoms. This way, freedom can be treated both in a positive sense, i.e. as an 
entitlement that such kind of authority imposes on particular citizens, and in a negative sense, i.e. as a protection which it offers in exchange for a certain amount of concessions for themself, e.g. in return for obedience (cf. Markus, 1999, p. 274). Such a concept of freedom can be found, for example, in Niccolo Machiavelli when he distinguishes, on the one hand, the freedom that is characteristic of grandi and, on the other, the one that is characteristic of popolo. In his comments to Livy, he writes that:

$[\ldots]$ in every republic there are two conflicting factions, that of the people and that of the nobles, it is in this conflict that all laws favorable to freedom have their origin, as may readily be seen to have been the case in Rome. (Machiavelli, 2007, p. 16)

The category of freedom is understood in a similar way by Thomas Hobbes, for whom this is clearly a transactional value; in return for peace, citizens give the sovereign the full power. To quote Hobbes, the sovereign "may use the strength and means of them all, as he shall think expedient, for their Peace and Common Defense" (Hobbes, 1996, p. 121).

Jean Jacques Rousseau offers as understanding of freedom that is completely new, because in its essence it is not political but moral. Here, freedom is no longer 'a child of power', but it becomes an independent value, assigned to every human being by their very nature. In other words, freedom is no longer considered the result of a subject remaining in a certain relation to the political authority, but is a value naturally belonging to every human being. Understood this way, it has only loose relationship to the category of power as it becomes 'a cousin of power', so to say. In this 'cousin relationship', freedom can be considered twofold. Firstly, in a negative sense, it stands in opposition to power (minimising power means maximising freedom). Secondly, in a positive sense, it functionally translates into power (maximising freedom means maximising power). In the mentioned negative aspect, freedom is treated as not being subjected to coercion or any other form of intervention from the political authority. Then one can consider freedoms that a given authority guarantees the citizens. In this sense, one has the right to use some talents, i.e. one is not obstructed in using what naturally belongs to them. In the mentioned positive aspect, freedom is understood as the ultimate source of power and as the basis for legitimisation of any political power; here the state does not only provide the guarantee of the freedom of citizens, but it is also the real expression of their collective free will. In this sense, one has the right to participate in shaping the social and political environment, i.e. one is endowed with some beyond-natural powers that allow them to transgress their subjectiveness, making it possible to influence a broader social context.

These two aspects of freedom differ considerably. While in the first case freedom is the opposite of the external political authority, in the second case it is its source. These aspects are fully separate; the implementation of one of them does not necessarily involve the implementation of the other. If only the negative aspect is present, the authoritarian system is the result. When the positive aspect is provided, but the negative aspect is totally absent, the society is likely to be on the verge of anarchy. Only in the case of the democratic system, whose particular characteristic is the phenomenon of self-reference of power, the simultaneous implementation of both mentioned aspects of freedom can be observed. 
The democratic order is based on maintaining the wobbly balance between the two forms of freedom. Therefore, democracy should not be understood as a static institutional legal creation, but, rather, as a dynamic structure, whose main function is to mediate in the decision-making process. The center of gravity of this structure shifts between two poles, i.e. political representation (politicians), on the one hand, and citizens (voters), on the other. ${ }^{1}$ When the former one gains a clear advantage, democracy takes on an authoritarian (and frequently, though not necessarily, ${ }^{2}$ illiberal) character. When, in turn, the latter ones dominate, the risk of a gradual atrophy of democratic demos emerges. In both cases, what disappears is the public space and, by the same token, the public debate. Also, the sense of social cohesion, and thus social responsibility, is another element that dissipates.

This is where I am intentionally introducing the concept of social responsibility. Taking into consideration that the contemporary understanding of political freedom is largely marked by the moral dimension of the concept of freedom, it should not be surprising that the problems I will point to in further parts of the essay have profoundly moral consequences, too. The involvement in the public space and acting in favour of the common good is not only the right of every citizen, but it also involves a special kind of responsibility. This is about collective responsibility, which, in principle, is not far from the form of responsibility that Alexandre Dumas illustrated using the famous verbal expression of the bond connecting the four musketeers, i.e. "One for all, and all for one". ${ }^{3}$

In this essay, I will focus primarily on political freedom understood in the positive aspect, i.e. based on the exercise of civil liberties by citizens. This interpretation of freedom is much wider than just understanding it within a narrow framework of autonomy and selfdetermination. Here, freedom is to be considered not from the perspective of being able to act, but from the perspective of being willing to act, and the actual limitations imposed on it by various social, economic, and political conditions. Therefore, following Carisa Showden, one could speak about political agency rather than just about political freedom. As she states:

I argue $[\ldots]$ that agency is in fact distinct from and broader than autonomy or freedom considered alone. Autonomy is self-governance, even if governing through a relational sense of self. Agency is autonomy plus options; thus, agency includes not only the personal but also the political. (Showden, 2011, p. 1)

\footnotetext{
${ }^{1}$ This is, of course, a simplification, because modern democracies are spread between at least three poles. In addition to the two already mentioned, there is a third one, namely international corporations (cf. Crouch, 2004, pp. 43-46).

${ }^{2}$ It should be remembered that authoritarian systems do not have to be illiberal. Fareed Zakaria provides examples of liberal authoritarianism throughout history, e.g. the British Empire or the Austro-Hungarian Monarchy (Zakaria, 1997, p. 29).

${ }^{3}$ Worth noticing is the fact that this slogan was taken over in 1868 by the Swiss in order to strengthen the sense of solidarity and social responsibility of the citizens of what was then a young federation.
} 
This positive - agential - face of political freedom is particularly interesting today, when we are increasingly coming across situations in which citizens voluntarily give up the possibility to exercise their political freedoms. One example is the decreasing level of attendance of European Union citizens during the EU and national parliamentary elections. In some countries, political indifference turns into distrust or even hostility towards liberties that democracy should guarantee its citizens. In more and more countries, a growing support for those political parties that explicitly seek to limit civil liberties can be observed. The most illustrative examples come from Russia, Turkey, Hungary, or Poland.

\section{3.}

If freedom is secured as an option only, but is not reflected by the actions of citizens, it is only an empty declaration. The lack of restrictions that could prevent one from achieving a given goal does not mean that one will actually strive for it. Importantly, I do not mean matters such as an unfortunate coincidence or, simply, a lack of luck. I am referring to more internal constraints that people put on their actions themselves, be it intentionally or not. In literature, a model example of this kind of a limitation is the fear of freedom, which results from the inability to take responsibility for one's own decisions.

In his classic work, titled Escape from Freedom, Erich Fromm turns attention to this 'dark' side of freedom, which is the burden of responsibility. Following the above-mentioned distinction between freedom in the negative and positive sense, the author notes that the latter one, by opening the field of possible choices, imposes the responsibility for the accuracy of one's decisions. This kind of responsibility is a burden that, for many people, can constitute baggage that is above their strength. It is much easier to rely on a decision that has been imposed top-down, for which an authority, a ruler, or even an abstract idea is responsible. As Fromm wrote his work in 1941, he considered this phenomenon primarily in the context of the birth of Nazism. He describes a special and complex psychological characteristic of a person subjected to such kind of the authoritarian regime; he does it by pointing to three characterological features: authoritarianism, destructiveness, and conformism. Although these traits found their particularly destructive manifestation in Nazi Germany, they were symptomatic not only of this brief episode from the $20^{\text {th }}$-century history. Fromm applies similar characteristics to the post-war capitalist societies and the democracies that emerged from them. He does not deny that in these societies political freedom has reached unprecedented levels. As he says, "Capitalism not only freed man from traditional bonds, but it also contributed tremendously to the increase of positive freedom, to the growth of an active, critical, responsible self" (Fromm, 1965, p. 128). He signals, however, that "at the same time it made the individual more alone and isolated and imbued him with a feeling of insignificance and powerlessness" (Fromm, 1965, p. 128). The reason for this negative phenomenon of the individualisation and atomisation of society was the capitalist principle of equality with regard to the right for open competition. Fromm was one of the first ones to notice the close and perplexed relationship between capitalist and democratic regimes and, thus, between the economic freedom and the 
political freedom. He also understood that one of the key aspects of the economic freedom, i.e. individuality, can be one of the main threats to the social and political life. As he stated, "This principle [namely] helped to sever all ties between one individual and the other and thereby isolated and separated the individual from his fellow men" (Fromm, 1965, p. 128). This kind of isolation and separation can lead, in consequence, to the development of attitudes such as egoism and egotism that, as a result, undermine the cohesion of the social fabric and the sense of social solidarity. Using Fromm's phrasing, one could say that "freedom has reached a critical point where, driven by the logic of its own dynamism, it threatens to change into its opposite" (Fromm, 1965, p. 297).

In his grim diagnosis, Erich Fromm draws attention to an extremely important aspect of political freedom that is often overlooked. Namely, political freedom is a freedom that takes place against the background of a broader community of individuals. In other words, although the source of political freedom lies in the individual, its range 'spreads' over the entire community. For this reason, the basic difficulty in exercising political freedom in the positive sense is that it cannot be turned into an imposed duty. Officially, citizens cannot be forced to make use of their political freedoms (though, of course, they can be effectively discouraged from it). By the means of creating a registration and penalty system (as it is, for example, in Argentina, Australia, and Belgium), citizens can be coerced into engaging in the political life. However, what is achieved by this method is merely an increase in the election turnout, not the improvement of the quality of citizens' use of their political freedoms. The difference lies in motivation. What drives citizens to participate in the elections in countries where it is considered a civic duty is self-interest and, more specifically, the fear of the consequences of not performing this type of duty. Political freedom, in turn, although it finds its manifestation, first and foremost, in the actions performed by individuals, is always 'aimed' at the interest of a specific community. The right to vote and the right to free speech are both rights assigned to individual citizens, but their broader meaning is about the transparent and representative functioning of a decision-making process within the whole community. Therefore, citizens who exercise their political freedoms should do so with a full awareness of their responsibility towards the community. This factor of responsibility results from the sense of belonging to that community and from the close interdependence of its interest with one's own aims, all of which makes political freedom a special phenomenon. It is a freedom that is assigned to individuals - or groups of individuals - for the sake of the interest of a wider community. When the political freedom of one person is breached, the freedom and interest of the entire political community is also violated. It should be recognised that when political freedom is carried out only out of duty, i.e. out of concern for self-interest and not from the sense of responsibility for a specific political community, it is a fake. The result is not making the collective responsibility stronger, but only confirming one's own interest, which is equivalent to the act of isolating and separating oneself from the community. 


\section{4.}

What seems to be particularly important today is the role of citizens in implementing the political freedom. This role, however, cannot be considered from the point of view of dry statistics only, i.e. the voter turnout, the level of party membership, or the support for the idea of the democratic order as such. The concept of democracy has already become so blurred that the question of satisfaction with the level of democracy has, to a large extent, become equivalent to the question of support for a given ruling party. Politicians who reach for populist slogans often assume a positive, pro-democratic face. Poland can serve as an example.

Compared to surveys conducted in 2016 and 2017, more respondents declare satisfaction with the functioning of democracy in Poland than dissatisfaction. The latest survey by the Centre for Social Opinion Research shows that for the first time since the last parliamentary elections, respondents satisfied with the functioning of democracy $(48 \%)$ outweigh the dissatisfied (43\%). Satisfaction increased - in relation to the result from August 2017-by 8 percentage points, while dissatisfaction fell by 9 points. (PAP/AH, 2018)

Also, a high voter turnout does not have to translate into the satisfactory condition of democracy. If voting is the only form of political commitment rather than the result of a broad, open public debate, it may well characterise highly atrophied and conflicted societies. It is sufficient to look into the voter turnout over the last two years in selected European countries. The results from France and Germany from $2017-74.5 \%$ and $75 \%$ respectively - do not differ much from the results recorded in 2018 in countries, whose democracies seem to be only nominal today. In countries such as Russia (67.5\%), Hungary (70.5\%), and Turkey $(87.0 \%)$, citizens also participated in the elections to the same extent as in France and Germany.

Instead of such indicators as the voter turnout or the declared support for the democratic system, one should focus on factors that allow for a diagnosis of the internal dynamics of the political system. In the case of democracy, attention should be paid primarily to the dynamics of the political dialogue. By the dynamics of the political dialogue I mean, first and foremost, the extent of social consultations and their actual impact on political decisions. Is this type of consultation only held in a group representing the same or similar political views, or does it embrace opposition parties as well? Do political representatives consult decisions with citizens and, the other way round, do citizens' appeals and protests have an impact on politicians' thinking process and subsequent decisions? Are those representing a different opinion treated as enemies or as eligible participants of the social dialogue? Do politicians treat citizens only in an instrumental way or do they count on their evaluation and feel the responsibility that arises from the act of legitimising their status as a political representation? All these questions boil down to one fundamental issue, namely the respect for people representing either different worldviews or a different political status.

The fact that one of the key problems of modern democracies is the lack of a political dialogue can be observed in that citizens are intentionally giving up their political freedoms. The reason for this lies in, above all, the sense of the pointlessness of conducting any 
political debate. It should be noted that the lack of need for any involvement in the public debate may result from two different elements. On the one hand, it might be about the feeling of no possibility to conduct any debate and, on the other, about the feeling of no need to conduct such a debate. The former motivation is characteristic of post-democratic regimes (as understood by Colin Crouch), while the latter one is typical of illiberal democracies (as understood by Fareed Zakaria). In the first case, we are dealing with the indifference of citizens who do not see it possible to have any influence on the government. In the second case, in turn, this attitude takes the form of hostility towards political opponents as those who are posing a threat to the vital interests of the state. Both these models, each of them critical in a specific way, are based on the phenomenon of polarisation of the public sphere: vertical (in the former situation) and horizontal (in the latter situation).

Although in the theoretical perspective both models constitute extremely contrasting proposals, from the historical point of view they are arranged along the same logic of the progressing crisis. What brings both models together is the gradual disappearance of the political dispute or, in other words, the process of appropriating the public space by one political option. What is missing in both models is the need for challenging opposing opinions and the respect for those who represent them. Both of these values form the basis of the democratic order and both are marked by mutual tension that is characteristic of any democracy, the maintenance of which seems to be one of the most difficult tests today.

\section{5.}

The extent of social polarisation is the criterion that makes it possible to accurately diagnose the quality of public debate. Polarisation involves the lack of coherence of demos, the isolation of interest groups which try to manipulate the distribution of power in various ways, and the inflow and flow of information within the public sphere ('inflow' here will also shape the Habermasian criteria of credibility). As Jennifer McCoy, Tahmina Rahman and Murat Somer write, "Polarization is activated when major groups in society mobilize politically to achieve fundamental changes in structures, institutions, and power relations" (McCoy, Rahman, \& Somer, 2018, p. 16).

Obviously, one can level the criticism by saying that opinion differences and disagreements are actually the soil of the democratic order. Democracy is a system where one of the main advantages is that it can manage conflicts peacefully. As the above-mentioned authors state, "Democracy is intended to be a system of governance to manage competing interests in society in a peaceful way" (McCoy, Rahman, \& Somer, 2018, p. 18). This consideration is valuable in that it forces one to make a significant distinction between two types of polarisation, i.e. political and ideological. The former one involves the opposition of perspectives, while the latter one is based on the opposition of camps. It is not possible to find any middle ground between two opposing camps just as easily as one could look at the same problem from two different perspectives. This opposition corresponds to the distinction, drawn by Chantal Mouffe (2005, pp. 8-34), between politics cultivated in the 
agonistic and antagonistic spirits. The agonistic policy does not perceive a political alternative as a threat, but as a complement to its own (by definition biased) perspective. In turn, the policy conducted in the spirit of antagonism treats all alternatives as a deadly threat to its own camp. The settlement within the agonistic model is considered as an enriching compromise, while within the antagonistic model it will be regarded as a failure or even a betrayal. Agonists see adversaries as those who enrich the environment, whereas antagonists think of the others as enemies.

Until recently, the classic political divisive line was the political opposition, i.e. right-left (republican option - democratic option). Today, however, this distinction has already become highly misleading. It is sufficient to look at the Polish political scene, where the ruling Law and Justice party (PiS) represents classically prosocial politics (borrowed from the left), but at the same time a strongly national one (derived from right-wing parties). In order to describe political divisions today, categories that do not have much in common with politics (e.g. those referring to religion, history, and nation) turn out to be much more useful. What Zdzisław Mach wrote in the early 1990s is still valid. As the author stated, "National identity and nationalism as its active expression in relations to the state often takes precedence over political identity" (Mach, 1993, p. 103). These words are as true today as they were when after the fall of communism nations began to regain the right to define themselves through their ethnic, cultural, and historical heritage. Needless to say, this process was sometimes extremely violent and tragic. However, the question should be asked about why a similar rhetoric still occurs today; why the issue of ethnic, national, and religious identity still holds a central place in the political debate; why nations which seem to have worked out their nationality issues long time ago still reach for the same ideological rhetoric (e.g. Marine Le Pen in France or Nigel Farage in Great Britain).

Defining a political identity through such strong ideological categories such as religion or nationality makes political parties increasingly separated from each other and more and more entrenched in their positions. As a result, in a political dispute there is no room for compromise, just as in the parties alone there is no room for any ideological deviations. On the one hand, it leads to the stratification of the public sphere, and, on the other, to its ossification. Fareed Zakaria provides some suggestion as to the reasons for this. He claims that the political system, guided exclusively by the democratic logic of the majority - and by its traditional relationship to liberal values being ignored - reaches for the most effective rhetorics of polarising values (religious, national, and ethnic), whose function is to clearly divide society into camps of supporters and opponents. The author writes that " [ ... ] without a background in constitutional liberalism, the introduction of democracy in divided societies has actually fomented nationalism, ethnic conflict, and even war" (Zakaria, 1997, p. 35). Such a radically defined rhetorics virtually removes the possibility of taking a moderate or centrist position. This kind of an uncompromising approach to the public debate implies a significant disruption, if not the radical relinquishment of the liberal status quo. What disappears is the axiological common ground, the role of which would be to connect all citizens above political, ideological, religious, and cultural divisions. However, one should note a certain limitation in Zakaria's way of thinking. To his mind, the 
blind pursuit of the democratic logic of the majority and, therefore, thinking in terms of the strong opposition between 'our majority' and 'your minority' is specific for countries where liberalism has not found the right footing yet. However, the author does not allow for the possibility that a mature and stable democratic system, raised on liberal foundations, can be deliberalised and fall into the same trap of thinking in narrow categories of the democratic majority.

\section{6.}

As mentioned above, social polarisation can follow two lines, i.e. vertical or horizontal. In the vertical plane, there occurs a separation of the political, economic, and media elites from individual citizens. In the horizontal plane, in turn, the separation goes through the demos itself, i.e. two opposing political options emerge, dividing citizens into two hostile camps. ${ }^{4}$

\subsection{Post-Democratic Order (Colin Crouch)}

The first of these processes has been thoroughly analysed and described by Colin Crouch. According to him, a democratic system should not be considered a stable institutional and normative structure, but as a process which constantly produces a particular distribution of power. The democratic system as an ideal is supposed to be spread along the line of political representation: the authority rests in the hands of citizens who, in order to run the system smoothly, select their political representatives from among themselves. However, though this vertical relation (demos-political representation) is crucial to democracy, it is the main 'drive' behind the democratic system only every now and then. Crouch claims that such ideal democracies happen only as a result of severe political crises. It is not only about the idealistic aspirations of citizens prevailing in these periods, but about the fact that in such transitional phases the distribution of power is still very fluid as no consolidated control centres have emerged yet. ${ }^{5}$ However, when such distinctive centres are created, a shift of the centre of gravity of the democratic system is inevitable. Citizens lose their importance and their political potential is taken over by political, economic, and media actors. Although this new arrangement still retains all the features of the democratic system, i.e. free elections and a periodically elected political representation, the burden of

\footnotetext{
${ }^{4}$ Each of these polarising processes can proceed alone. Most often, however, they accompany each other. The lack of a real public debate leads to the theatricalisation of the political life, which results in its dramatisation, i.e. presenting the political scene as a field where fundamental values (good/evil, truth/falsity) clash against each other. In such a situation, it is difficult to imagine the possibility of any debate or mediation, let alone the possibility of a compromise.

${ }^{5}$ According to the author, such 'golden periods' can be noticed e.g. in the case of media development history. At the beginning of the $20^{\text {th }}$ century, the press was a forum of free thought and continued this policy until it was dominated by large media corporations. The same can be observed at the beginning of the $21^{\text {st }}$ century in the case of the Internet. This initially open and a very flexible platform of exchange of opinions has now, i.e. in the second decade, become a tool of pressure and information manipulation.
} 
decisions is shifting from the demos to these newly emerging decision-makers. For this reason, Crouch still considers this kind of system as democratic, but he claims that it is some kind of an aberration of a fully democratic system. Hence, he defines such a political system as 'post-democratic'. Post-democratic systems are, therefore, characteristic of late stages of the development of liberal democracies, where the centres of power become ossified and the political process gets highly bureaucratic. The key to this type of a system is the loosening of the axis connecting politicians and citizens. On the one hand, politicians are less and less interested in the opinion of their voters and are increasingly influenced by other decision-making centres, namely business and media. The voter is treated not as a source of the political process, but as its object. The goal of politicians is to influence voters in such a way so that in the next elections they cast their votes in favour of the political option declared by them. On the other hand, voters who can recognise that they are only the receiving end of the political process distance themselves from politics, treating it more as a spectacle than a real decision-making process, which could have a real impact on their life situation. It can be widely discussed what the reasons of such a tendency are; in each historical period the causes were different, i.e. at the beginning of the last century they were very different than today. As for the current phase of the de-democratisation of liberal systems, Crouch focuses primarily on causes such as globalisation and the resultant commercialisation and mediatisation of social and political relations.

However, no matter what reasons one considers responsible for the current condition of liberal systems, one can undoubtedly notice the phenomenon of an increasing scepticism towards the key ideas lying at the foundation of democracy, including the idea of political representation and basic liberal values. This scepticism can be spotted both on the 'left' and the 'right' sides of the political scene. The supporters of the increased citizens' participation in the political debate are full of hope with regard to integrating modern information technologies into the political process. This would actually strengthen the position of the citizens, giving them a tool to influence the political process almost at any time (not, as it is now, only once every few years). The already existing projects of information systems (e.g. liquid democracy, known also as delegative democracy) allow some people to even hope for a complete elimination of the political representation system (political parties) and the return to the idea of a direct democracy. On the other hand, the critics of liberal values, usually sitting on the right side of the political aisle, recognise that they constitute an obstacle to the efficient functioning of the state apparatus, and that they hinder the effective protection of national interests. The former attitude is undoubtedly the result of the phenomenon that Colin Crouch describes as 'post-democracy'. The latter one, in turn, is the source of the phenomenon that Fareed Zakaria calls 'illiberal democracy'.

\subsection{Illiberal Order (Fareed Zakaria)}

The essay by Fareed Zakaria, which has already been referred to, is interesting in that it looks at democracy somewhat suspiciously. Democracy, as Zakaria emphasises, does not have to be liberal at all. One can easily imagine political systems that, from the institutional 
point of view, are governed by democratic rules, but that function in violation of basic human and civil rights (e.g. the right to free assembly or to freedom of speech). As the author write, "Democratically elected regimes [...] are routinely ignoring constitutional limits on their power and depriving their citizens of basic rights and freedoms" (Zakaria, 1997, p. 22). One does not have to look far to find exemplifications of this phenomenon; such political systems are prevailing in Russia, Turkey, or Hungary.

Zakaria explains this phenomenon by referring to one fundamental assumption; in his opinion, a stable democracy can develop only on the basis of deeply rooted liberal values, not the other way around. He claims that "constitutional liberalism has led to democracy, but democracy does not seem to bring constitutional liberalism" (Zakaria, 1997, p. 28). In the $19^{\text {th }}$ century and at the beginning of the $20^{\text {th }}$ century, the main promoters of liberal values were countries whose regimes were far from democracy. These were authoritarian states, such as the Austro-Hungarian Monarchy or the British Empire. Their liberal orientation, however, has created the ground for the later formation (as late as after the First World War) of the liberal democracies of Western Europe and Central Europe. However, when such a stable, normative foundation in the form of liberal values is absent, democratic mechanisms can easily be distorted and contribute to radical social divisions and conflicts rather than to cohesion and greater social solidarity.

Zakaria's text, written in the late 1990s, presents a clear picture of a consistently developing system of liberal democracy (this impressive consistency even prompted Francis Fukuyama to announce the end of political history in 1992). Today, more than twenty years later, this picture seems exaggeratedly idealistic. In countries where democracies seemed to be deeply permeated with liberal values not so long ago, the liberal and pluralist attitude has been more and more criticised; an increasing number of citizens are in favour of governments ruling with an 'iron fist', which will allegedly preserve the national identity and defend national interests effectively. Such postulates result in deep social divisions which are exploited by politicians calculating their moves strictly along the logic of a democratic majority.

In the early 1990s, Donald Horowitz drew attention to the negative impact of social divisions on the condition of democracy. However, in the article titled "Democracy in Divided Societies" he focused mainly on ethnic divisions. In 1993, he included Poland, Hungary, and the Czech Republic as examples of dynamically developing liberal democracies, at the same time opposing them to other countries of Central and Eastern Europe, such as Slovakia, Bulgaria, and Romania. He recognised the lack of deep ethnic divisions as the main reason for their success. As he wrote, "Democracy has progressed furthest in those East European countries that have the fewest serious ethnic cleavages (Hungary, the Czech Republic, and Poland)" (Horowitz, 1993, p. 19). Zakaria follows Horowitz' reasoning with regard to recognising ethnic divisions as the main enemy of liberal democracy. Let us quote Zakaria once again when he says that "in societies without strong traditions of multi-ethnic groups or assimilation, it is easiest to organize support along racial, ethnic, or religious lines" (Zakaria, 1997, p. 35). In the face of today's cases of illiberal democracies, however, it seems necessary to expand Horowitz' thesis to all societies that are strongly 
conflicted ideologically. Currently, ideological divisions are equally destructive as ethnic divisions; they are effectively pushing the former model countries of Central and Eastern Europe from their democratic trajectories. Therefore, what is particularly dangerous for democracy today is all sorts of divisions that go so deeply that they result in social rifts that seem impossible to overcome.

7.

According to some researchers, e.g. Patrick J. Deneen, deep ideological divisions that can be witnessed today and that constitute a fertile ground for all kinds of illiberal and xenophobic slogans grow out of the errors lying at the foundation of liberalism itself. It is not as Zakaria wanted it to be, i.e. that only democracy can be dangerous if it is not accompanied by liberalism. Liberalism itself can also be dangerous, because the phenomena emerging from it may remain in contradiction with the values of freedom and equality of citizens. These contradictions can be twofold. They can be logical, i.e. they can stem from the very premises of liberalism. However, they can also be factual, i.e. they can be the result of the actual application of liberal principles.

In the first case, the problem lies in the very meaning of liberalism. This concept seems to contain an internal contradiction. Following the analyses by John Gray, four components of liberalism should be distinguished: individualism, egalitarianism, universalism, and meliorism (Gray, 2003, p. xii). ${ }^{6}$ Liberalism is universalist on the one hand, but adheres to individualism on the other. Thus, it leaves a clear way for relativising its own foundations and, consequently, undermining its universal status. The best illustration of this point is the impossible-to-settle debate on the validity of the multicultural policy. The postulate of respect for all cultures stands in contradiction with the demand for respect for individual rights. ${ }^{7}$ Liberalism, therefore, in order to maintain its 'holding', so to say, must clearly set limits to any acceptable criticism of its position. These borders are constantly changing, giving the impression of a completely arbitrary set of frames which are more the subject of an occasional fashion than substantial arguments.

Another objection to the liberal position is its scarce ideological offer. The universal character of liberalism leaves it almost completely devoid of any practically applicable meaning. Therefore, it is difficult to erect any coherent view of the world based on the fundamental premises of liberalism. This prompts some people to reach for more complete

\footnotetext{
${ }^{6}$ In his considerations, Gray overlooked one important determinant of liberalism, i.e. rationalism.

${ }^{7}$ Charles Taylor argues that liberalism is not a neutral ideological proposal that could be considered a common ground connecting different cultural options. As he states, "Liberalism is not a possible meeting ground for all cultures", later adding that "liberalism is also a fighting creed" (Taylor, 1994, p. 62). William Galston recognises Rawls and Dworkin as the most important representatives of this liberal camp, describing their attitude as "rationalist humanism".
} 
ideological proposals, e.g. those offered by religious or political ideologies. Michael Ignatieff expresses it quite perversely, but at the same time very accurately, when he says that:

Liberalism thought it had won the political battle by forcing religion out of the public sphere and relegating questions about the meaning and mystery of life to the private sphere; but while this may have pacified politics, it has left a hunger for shared public conceptions about the purpose of life. For this religion offers a consolation that even some liberals find themselves turning back to as they stare into the endlessly receding horizon of liberal democracy. (Ignatieff, 2018, p. 60)

The attempt to leave all ideological choices within the private sphere of each one of the citizens has resulted in stripping the liberal image of any deeper meaning. What has remained is an idealised picture of a fully rational (today, however, less and less rational) consumer. In this situation, the voice is given to the identity-oriented demands that are formulated by right-wing politicians.

When looking at liberal politics from a practical perspective, in turn, it should be noted, after Patrick J. Deneen, that the liberalisation of fields such as politics, economics, education, science, and technology has not led to the promised liberation of the humanity, but, rather, to the emergence of new social divisions. As the author writes in the book titled Why Liberalism Failed:

Liberalism has failed - not because it fell short, but because it was true to itself. It has failed because it has succeeded. As liberalism has 'become more fully itself,' as its inner logic has become more evident and its self-contradictions manifest, it has generated pathologies that are at once deformations of its claims yet realizations of liberal ideology. (Deneen, 2018, p. 3)

Therefore, liberalism, while trying to formulate a universal (i.e. international and intercultural) ideological platform, has led to the emergence of social frustration and opposition. Some began to turn away from it due to the sense of disillusionment with its ideas, while others rejected it due to feeling excluded politically, economically, and socially. Yet another group of citizens began to perceive it as a camouflaged version of Western imperialism. That which was supposed to connect has now begun to strongly divide. The reasons for that can be found in the very roots of liberalism, i.e. in the utopian project of the liberal mindset, which is about creating a universal status quo that could be accepted by everyone.

\section{8.}

This kind of liberal status quo is highly criticised by Chantal Mouffe. As she claims in the book The Return of the Political, "In fact the ambition of 'political liberalism' is to formulate a definitive list of rights, principles and institutional arrangements that are unassailable and will create the basis of a consensus that is both moral and neutral" (Mouffe, 1993, p. 139). A fundamental problem of liberalism is located at the intersection of these two last concepts, namely the possibility of combining a neutral attitude with a morally significant attitude. In John Rawls' Theory of Justice, these concepts seem to be reconciled in a somewhat idealistic construction, namely the 'original position'. Mouffe, in turn, 
claims that this kind of attempt to reconcile morality and neutrality is doomed to failure. This key postulate of liberalism basically boils down to the repression of all diversity and of any dispute in the public sphere, and to pushing them into the private sphere. In publico, only those questions are permissible that can be resolved by means of a rational debate, whereas only in privato can feature those issues that produce the most serious divisions, i.e. the worldview-related ones. Liberalism, therefore, does not seem to answer questions or solve problems, but only sweeps them under the carpet of the private sphere. As Mouffe states, "All controversial issues are taken off the agenda in order to create the conditions for a 'rational' consensus" (Mouffe, 1993, p. 140). In her opinion, this kind of politics inevitably leads to the elimination of the political reality (understood, after Carl Schmitt, as das Politische - the political). The liberal vision of politics as a sphere of a rational debate and negotiations between individuals is, according to Mouffe, a serious distortion of the real character of the political sphere and, in fact, completely ignores the issue of the distribution of power and social antagonism. Hence, it is not surprising that liberalism cannot cope with both vertical polarisation that results from an uneven distribution of power, and horizontal polarisation that results from deep ideological social antagonisms. This relative order and peace that liberalism postulates is, therefore, obtained at the price of a serious disadvantage. It is, as Mouffe claims:

$[\ldots]$ only possible at the cost of denying the irreducible antagonistic element present in social relations, and this can have disastrous consequences for the defense of democratic institutions. To negate the political does not make it disappear, it only leads to bewilderment in the face of its manifestations and to impotence in dealing with them (Mouffe, 1993, p. 140)

These manifestations of the political cannot, however, get discharged in the public sphere, since liberal status quo generally excludes them as unacceptable. Therefore, they get displaced into the 'grey zone'. There they become an ideal breeding ground for all sorts of populisms and extremisms.

Populism, understood as a kind of a parasite on the wasteland of political liberalism, is a position that is exceptionally fluid and difficult to grasp. It is impossible to precisely define it within the 'right-left' opposition, since it is trying to effectively control the entire spectrum of social frustration, anger, and resentment. The attempts to define populism must, therefore, come to naught. However, this is due to the inclination to treat populism as a political option, whereas in reality this option should be termed as 'anti-political'. Populism is born, develops and constantly re-defines itself in contradiction with the dominant political options, the so-called political establishment; populists present and illuminate it in such a way as to create as many conflict lines as possible. Being the fruit of an insufficiently representative democracy, populism can serve as an alarm signal, indicating the need for change, i.e. going in the direction of a significant widening of the scope of a public debate. As Mouffe states in the book titled On the Political:

It is high time to realize that, to a great extent, the success of right-wing populist parties comes from the fact that they articulate, albeit in a very problematic way, real democratic demands which are not taken into account by traditional parties. (Mouffe, 2005, p. 71) 
It turns out that liberalism is not at all a remedy for all kinds of ills of a modern democracy. It is, rather, part of the problem, which is called 'populism' today. The only solution that can be found in this case is the reactivation of a lively and flexible public debate, i.e. the sphere of the political that Mouffe writes about and that is nothing more than the field of political freedom.

9.

Political freedom should not be understood as a stable field that can be described by a series of laws and principles. This kind of freedom would be nothing but an element of a broadly defined liberal programme, an element of a broader liberal policy. Political freedom, in Mouffe's view, should be understood in the spirit of the political, i.e. as an indefinite area of open discourse which is constantly subjected to redefinition. Mouffe describes this sphere from the perspective of a political scientist, while Colin Crouch investigates it as a sociologist when he writes that "democratic politics needs a vigorous, chaotic, noisy context of movements and groups. They are the seedbeds of future democratic vitality" (Crouch, 2004, p. 120). There is also an analysis provided by Helmuth Plessner, who considers the subject from the philosophical point of view.

What has been described above in terms of political and social postulates, in Plessner's philosophical anthropology takes the form of a deepened description of the human nature. This nature, as the German philosopher claims, is based on the human ability to grasp themself in the act of reflection. For a human being there is not only 'here' (Heidegger's categorisation-Dasein), but they also go beyond themself. In this so-called 'eccentric positionality' they keep distance from themself and stay in a place that Plessner calls 'utopian'. This place is non-existent or is nowhere, because it is not defined in any particular way. It is a place of pure reflection, one that is shared by all people. It is not a place occupied by any individual self or a group of individual selves, but by the pure self, where the human being becomes a fully 'representable and substitutable' being, i.e. vertretbar und ersetzbar (Plessner, 1980, p. 421). This concept brings to mind Rousseau's idea of the general will. In The Social Contract, it can be read that:

[...] in place of the particular individuality of each contracting party, [the] act of association produces a moral and collective body, composed of as many members as the assembly has voices, and which receives from this same act its unity, its common self (moi), its life, and its will. (Rousseau, 2002, p. 164)

The concept of the self, common to all citizens, coincides with Plessner's concept of the pure self, which is the constitutive principle for the world of spirit (Mitwelt). The place where the human being stands is, therefore, undefined and gains its name only as a result of a collective act of reflection.

The collective act of reflection is political, anthropological, and philosophical; the meaning of humanity is being established through it each and every time anew. In the book titled Macht und menschliche Natur, Plessner writes that "to treat the man as an open 
question is to leave open the decision about the primacy of philosophy, anthropology, and politics" (Plessner, 2003, p. 221). A human being is a political being by the very fact of the necessity to constantly self-identify and to determine their place in the cosmos; it is the power through which they constantly keep themself in the line of humanity. Therefore, the political is not the result of any social contract; it is not-as Rousseau would have liked it - a remedy for the 'original sin' that was allegedly committed in the distant past by the humanity. Rather, it results from the human nature itself and from the fact that a human being as an indefinite being - and in this sense open - is forced to be constantly overcoming themself and controlling themself. As Plessner writes, "In this self-relationship of indeterminacy man recognizes themself as the power (Macht) and discovers themself for his life, theoretically and practically, as an open problem" (Plessner, 2003, p. 188).

Political freedom is what takes place in this sphere of the original human openness. It should not be understood as an ordered and regulated sphere of political life, because then it would be the reverse of what it was supposed to be in the first place. Therefore, it should not be understood in terms of a stable, safe status quo. It should be liberal instead. In order to effectively channel human openness, political freedom should be understood as an uneasy, chaotic, sometimes even shouting (and colourful at the same time) field, where views are manifested, exchanged, and negotiated. Only then will it be able to fulfil its function, both anthropologically and politically.

\section{References}

Crouch, C. (2004). Post-Democracy. Cambridge, UK: Polity Press.

Deneen, P. J. (2018). Why Liberalism Failed, New Haven, CT: Yale University Press.

Fromm, E. (1965). Escape from Freedom. New York, NY: Avon Books.

Gray, J. (2003). Liberalism. Minneapolis, MN: University of Minnesota Press.

Hobbes, T. (1996). Leviathan. Cambridge, UK: Cambridge University Press.

Horowitz, D. (1993). Democracy in Divided Societies. Journal of Democracy, 4(4), 18-38.

Ignatieff, M. (2018, June 28). Making Room for God. New York Review of Books, 59-60.

Markus, G. (1999). On Freedom: Positive and Negative. Constellations, 6(3), 273-289.

Machiavelli, N. (2007). Discourses on Livy. New York, NY: Dover Publications.

McCoy, J., Rahman, T., \& Somer, M. (2018). Polarization and the Global Crisis of Democracy: Common Patterns, Dynamics, and Pernicious Consequences for Democratic Polities. American Behavioral Scientist, 62(1), 16-42.

Mach, Z. (1993). Symbols, Conflict, and Identity: Essays in Political Anthropology. New York, NY: State University of New York Press.

Mouffe, Ch. (1993). The Return of the Political, London, UK: Verso. 
Mouffe, Ch. (2005). On the Political. London, UK: Routledge.

PAP/AH. (2018) Polacy zadowoleni z demokracji. Retrieved from: https://www.wnp.pl/parlamentarny/spoleczenstwo/polacy-zadowoleni-z-demokracji,31964.html

Plessner, H. (1980). Die Stufen des Organischen und der Mensch, Gesammelte Schriften, Vol. IV. Frankfurt am Main, Germany: Suhrkamp Verlag.

Plessner, H. (2003). Macht und menschliche Natur. Gesammelte Schriften, Vol. V. Frankfurt am Main, Germany: Suhrkamp Verlag.

Rousseau, J. J. (2002). The Social Contract. New Haven, CT: Yale University Press.

Sebastian, M. (2016). For Two Thousand Years. London, UK: Penguin Random House.

Showden, C. R. (2011). Choices Women Make: Agency in Domestic Violence, Assisted Reproduction, and Sex Work. Minneapolis, MN: University of Minnesota Press.

Zakaria, F. (1997). The Rise of Illiberal Democracy. Foreign Affairs, 76(6), 22-43. 